\title{
NOT E
}

\section{Structure of GL-1a, A Major Neutral Glycolipid, from Sulfolobus acidocaldarius N-8}

\author{
Akihiko SugAi ${ }^{\mathrm{a}, *}$, Ikuko UdA ${ }^{\mathrm{a}}$, Norio KurosawA ${ }^{\mathrm{b}}$, Akio SHIMIZU ${ }^{\mathrm{b}}$, \\ Masamichi IKEGUCHI ${ }^{\mathrm{b}}$, Yuko H. ITOH ${ }^{\mathrm{b}}$, and Toshihiro ITOH ${ }^{\mathrm{a}}$ \\ ${ }^{a}$ Division of Chemistry, Center of Liberal Arts and Sciences, Kitasato University \\ (Sagamihara-shi, Kanagawa-ken, T228) \\ b Department of Bioengineering, Faculty of Engineering, Soka University \\ (Hachioji-shi, Tokyo, ₹192)
}

Examination was made to determine the structure of a major neutral glycolipid (GL-1a) from Sulfolobus acidocaldarius $\mathrm{N}-8$. NMR indicated GL-1a to have a structure in which a glucose is linked via a glycosidic bond at the $\beta$-position to the ring of calditol, 2-hydroxymethyl-1-(2,3-dihydroxypropoxy)$2,3,4,5$-cyclopentanetetraol, in calditoglycerocaldarchaeol (caldityl-glyceryl-dialkyl-tetraether core lipid).

\section{Introduction}

More than $70 \%$ of the lipids in Sulfolobales, thermoacidophilic archaebacteria, are composed of the lipids in which a polar group is linked with calditoglycerocaldarchaeol (CGCOH, caldityl-glyceryl-dialkyltetraether core lipid) possessing the characteristic polyol called calditol. The $\mathrm{CGCOH}$ is a tetraether-type core lipid in which two $\mathrm{C}_{40}, 16,16^{\prime}$-biphytanyl diols, are bonded through ether linkages with one calditol and one glycerol $^{1), 2)}$. In a previous paper we reported that the structure of calditol is 2hydroxymethyl-1-(2,3-dihydroxypropoxy )2,3,4,5-cyclopentanetetraol ${ }^{3)}$.

In this paper, we clarified the bonding sites of the hydrocarbon chains to the calditol of $\mathrm{CGCOH}$ and the structure of the major neutral glycolipid (GL-1a) of Sulfolobus acidocaldarius $\mathrm{N}-8$ in which one hexose is linked with one CGCOH.

\section{Experiments}

\section{$2 \cdot 1$ Chemicals.}

Chloroform and methanol were of reagent grade and were freshly distilled before use.

Corresponding author : Akihiko SUGAI
Other organic and inorganic reagents, of the highest analytical grade commercially available, were used without further purification.

2.2 Growth of the bacterium and the preparation of lipids.

$S$. acidocaldarius $\mathrm{N}-8$, extremely thermoacidophilic archaebacterium isolated from the acidic hot spring of Noboribetsu in Japan was grown at $\mathrm{pH} 2.5,75^{\circ} \mathrm{C}$, and the lipids were prepared as previously described $^{3)}$. Total lipids were fractionated on a DEAE-Sephadex A-25 column $(30 \mathrm{~mm} \times$ $20 \mathrm{~cm}$ ) into neutral lipids and acidic lipids. From the neutral fraction, GL-1a was purified by TLC. CGCOH was prepared from the methanolysis products of the GL-1a. The diglycerocaldarchaeol (diglyceryl- dialkyl-tetraether core lipid) was prepared from $\mathrm{D}^{-}$glucosyl ( $\left.\beta 1-3\right)-\mathrm{D}^{-}$galactosyl $(\beta 1-1)$ diglycerocaldarchaeol by methanolysis. Acetylation of the core lipids and GL-1a were carried out with a mixture of acetic anhydride/pyridine $(2: 1, \mathrm{vol} / \mathrm{vol})$ at $60^{\circ} \mathrm{C}$ for $12 \mathrm{~h}$.

\subsection{Analytical instruments}

Spectra of fast atom bombardment mass (FAB-MS) were obtained using a JMS DX-300 (JEOL) in the positive mode with a 
matrix of 3 -nitrobenzyl alcohol. ${ }^{1} \mathrm{H}$ and ${ }^{13} \mathrm{C}$ NMR spectra were obtained using a JNM-A 500 (JEOL) at $500 \mathrm{Mz}$ and $75 \mathrm{Mz}$ in $\mathrm{CDCl}_{3}$, respectively. Chemical shifts were given in ppm relative to tetramethylsilane (TMS) as internal standard. Gas-liguid chromatography (GLC) was performed using a Hitachi 163 gas chromatograph equipped with $3 \%$ OV-101 $(3 \mathrm{~mm} \times 2 \mathrm{~m})$ at $180^{\circ} \mathrm{C}$ for the trimethylsilylated sugars, and with $2 \%$ Dexsil $300 \mathrm{GC}(3 \mathrm{~mm} \times 1 \mathrm{~m})$ at increasing temperature from $100^{\circ} \mathrm{C}$ to $300^{\circ} \mathrm{C}$ at a rate of $15^{\circ} \mathrm{C} /$ min for the hydrocarbons.

\section{Results and Discussion}

After methanolysis of GL-1a, CGCOH was detected as a core lipid by TLC. $\mathrm{C}_{40}$ isopranoid chains of the $\mathrm{CGCOH}$ prepared from GL-1a were investigated by GLC since it has been known that the biphytanyl chains contain from zero to four cyclopentane rings ${ }^{4) \sim 6 \text { ) }}$ and the cyclization in the chains is sensitive to the growth temperature $^{4)}$. In this $\mathrm{CGCOH}$, the results of GLC analysis of the isopranoid chains showed that the bicyclic type of biphytanyl chain was the major component (68\% overall), and tricyclic type was $28.4 \%$, and acyclic, monocyclic and tetracyclic were minor, respectively, $0.3 \%, 1.0 \%$ and $2.3 \%$. The value of the average cyclizations for the biphytanyl chains calculated according to the formula [ $\%$ monocyclic $+2 \times \%$ bicyclic $+3 \times \%$ tricyclic $+4 \times \%$ tetracyclic) $\left.\times 10^{-2}\right]$ was 2.31 , which showed more extensive cyclization than other lipids (the average cyclizations of the biphytanyl chains prepared from the total lipids is 2.16). The chemical shift of acetylated $\mathrm{CGCOH}$ is shown in Table-1. The assignment of each chemical shift was investigated by double quantum filter correlated spectroscopy, rotating frame Overhauser enhancement spectroscopy, homonuclear Hartman-Harn spectroscopy, and ${ }^{1} \mathrm{H}^{-}$

Table-1 ${ }^{13} \mathrm{C}$ NMR chemial shifts and ${ }^{1} \mathrm{H}$ NMR chemical shifts for acetylated calditoglycerocaldarchaeol $(\mathrm{Ac}-\mathrm{CGCOH})$ and acetylated $\mathrm{GL}-1 \mathrm{a}\left(\mathrm{Ac}^{-}\right.$ GL-1a)

The Chemical shifts are in $\mathrm{CDCl}_{3}$. Values are given in ppm downfield from TMS as internal standard.

\begin{tabular}{|c|c|c|c|c|c|}
\hline \multirow[b]{2}{*}{ Position } & \multirow[b]{2}{*}{ Carbon No. } & \multicolumn{2}{|c|}{${ }^{1} \mathrm{H}$ NMR } & \multicolumn{2}{|c|}{${ }^{13} \mathrm{C}$ NMR } \\
\hline & & $\mathrm{Ac}-\mathrm{CGCOH}$ & Ac-GL-1a & $\mathrm{Ac}-\mathrm{CGCOH}$ & $A c-G L-1 a$ \\
\hline \multirow{9}{*}{ Calditol } & 1 & 3.66 & 3.58 & 71.75 & 71.75 \\
\hline & 2 & 3.54 & 3.50 & 77.64 & 77.66 \\
\hline & 3 & 3.44 & 3.41 & 71.06 & 71.03 \\
\hline & $1^{\prime}$ & 4.22 & 4.17 & 85.10 & 84.48 \\
\hline & $2^{\prime}$ & - & - & 87.22 & 87.44 \\
\hline & $3^{\prime}$ & 5.46 & 5.51 & 73.00 & 72.64 \\
\hline & $4^{\prime}$ & 5.36 & 4.28 & 73.26 & 79.00 \\
\hline & $5^{\prime}$ & 5.47 & 5.41 & 80.37 & 80.68 \\
\hline & $6^{\prime}$ & $4.54 \quad 4.88$ & $4.22 \quad 4.47$ & 59.08 & 59.56 \\
\hline \multirow{3}{*}{ Glycerol } & 4 & $4.10 \quad 4.19$ & $4.10 \quad 4.19$ & 64.17 & 64.13 \\
\hline & 5 & 3.61 & 3.61 & 76.66 & 76.66 \\
\hline & 6 & 3.47 & 3.47 & 70.04 & 70.03 \\
\hline \multirow{6}{*}{ Glucose } & $1^{\prime \prime}$ & - & 4.57 & - & 100.50 \\
\hline & $2^{\prime \prime}$ & - & 4.92 & - & 71.28 \\
\hline & $3^{\prime \prime}$ & - & 5.16 & - & 72.69 \\
\hline & $4^{\prime \prime}$ & - & 5.05 & - & 68.38 \\
\hline & $5^{\prime \prime}$ & - & 3.65 & - & 71.92 \\
\hline & $6^{\prime \prime}$ & - & $4.12 \quad 4.22$ & - & 61.79 \\
\hline
\end{tabular}

*- ; absent. 


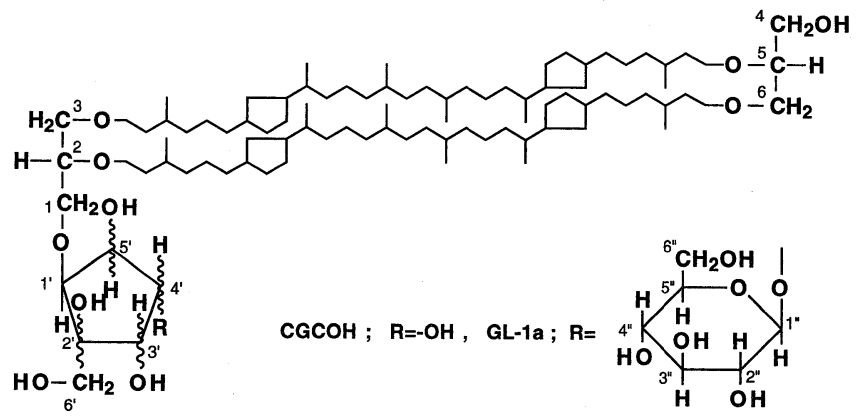

m; a satisfactory conclusion could not be drawn from NMR.

$\mathrm{CGCOH}$; calditoglycerocaldarchaeol

Fig.-1 Proposed structure of GL-1a and calditoglycerocaldarchaeol.

detected multiple quantum coherence. Also, the assignment of $\mathrm{C}-4, \mathrm{C}-5$ and $\mathrm{C}-6$ of CG$\mathrm{COH}$ was determined in comparison with the shift of the acetylated diglycerocaldarchaeol. When the chemical shifts in $\mathrm{CDCl}_{3}$ of the calditol portion of acetylated $\mathrm{CGCOH}$ were compared with the chemical shifts of acetylated calditol in $\mathrm{DMSO}^{3)}$, the $\mathrm{C}-2$ and C-3 chemical shifts of the glycerol-like portion of calditol in $\mathrm{CGCOH}$ were significantly shifted to downfield for the shifts of acetylated calditol. Also, $\mathrm{H}-2$ and $\mathrm{H}-3$ showed a significant shift upfield. From these results, it was elucidated that the binding position of the hydrocarbon chain exists in $\mathrm{C}-2$ and C-3.

It was confirmed by GLC that the constituent sugar of GL-1a is glucose and the molar ratio to $\mathrm{CGCOH}$ is $1: 1$. From the analysis of its constituents, the structure of GL-1a appears as glucopyranosyl-CGCOH. To examine the binding position of glucose for $\mathrm{CGCOH}$, chemical shifts of the acetylated GL-1a and acetylated CGCOH were compared as shown in Table-1. The results showed that the C-4' of the calditol part of the GL-1a was significantly shifted downfield by about $6 \mathrm{ppm}$ and $\mathrm{H}^{-}{ }^{\prime}$ ' upfield by about $1 \mathrm{ppm}$ for the $\mathrm{CGCOH}$. Furthermore, a strong NOE signal was observed at the $\mathrm{H}-4$ ' of the cyclopentane ring of calditol and the $\mathrm{H}-1$ " of glucose. From the fact that a shift value of $\mathrm{C}-1$ " of glucose was 100.5 ppm, it became evident that GL-1a is a gly- colipid in which the $\mathrm{C}-1$ " part of glucose is linked with the $\mathrm{C}-4$ ' of the calditol of CG$\mathrm{COH}$ by a glycosidic bond. The configuration at the anomeric centre of glucose was inferred to be $\beta$, on the basis of the value of the $J_{\mathrm{H}-1}$ ", $\mathrm{H}-2^{\prime} \cdot(7.6 \mathrm{~Hz})$. In GL-1a, there have existed numerous molecular species which sorted according to the difference in the number of cyclopentane rings in hydrocarbon chains constituting their lipid cores, and these postulated molecular formula is 1609.3 1625.4; $\mathrm{C}_{98} \mathrm{H}_{176 \sim 192} \mathrm{O}_{16}$. Measuring the positive FAB-MS spectrum of GL-1a, many molecular ion peaks were obtained showing $1618(\mathrm{M}+1)$ as its main peak. From analytical results of hydrocarbon chains mentioned and the main molecular ion peak of GL-1a, we found that the structure of main molecular species of GL-1a is same one as shown in Fig. -1 . Since GL-1a is comprised of $\mathrm{CGCOH}$, the structure is more stable form than the glycolipids consisted of diglycerocaldarchaeol.

(Received July 31, 1995)

\section{References}

1) M. De Rosa, A. Gambacorta, B. Nicolaus, B. Chappe, and P. Albrecht, Biochim. Biophys. Acta, 753, 249 (1983).

2) M. De Rosa, A. Gambacorta, B. Nicolaus, and J.D. Bu'Lock, Phytochemistry, 19, 821 (1980).

3) A. Sugai, R. Sakuma, I. Fukuda, N. Kurosawa, Y.H. Itoh, K. Kon, S. Ando, and T. 
Itoh, Lipids, 30, 339 (1995).

4) M. De Rosa, E. Esposito, A. Gambacorta, B. Nicolaus, and J.D. Bu'Lock, Phytochemistry, 19, 827 (1980).

5) M. De Rosa, S. De Rosa, A. Gambacorta, B. Nicolaus, and J.D. Bu'Lock, Phytochemistry, 19, 249 (1980).

6) M. De Rosa, A. Gambacorta, B. Nicolaus, B. Chappe, and P. Albrecht, Biochim. Biophys. Acta, 753, 249 (1983).

\author{
Sulfolobus acidocaldarius N-8の \\ 主要中性糖脂質 GL-1a の構造

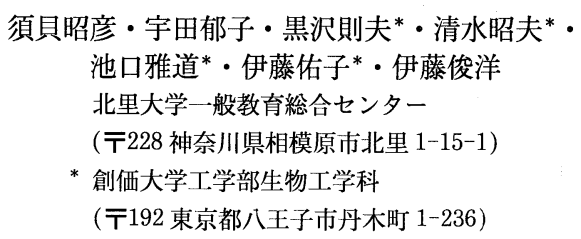

Sulfolobus acidocaldarius N-8 の主要中性糖脂質 GL-1a の構造について調べた。GL-1a は, calditoglycerocaldarchaeol（カルジチルグリセリルダイアル キルテトラエーテル脂質骨格) 中の calditol, 2-ヒドロ キシメチル-1-(2,3-ジヒドロキシプロポキシ)-2,3,4,5シクロペンタンテトラオール, のリング部分にグルコー スが $\beta$ 位でグリコシド結合したものであることが NMR によって明らかになった。

（連絡者 : 須貝昭彦） 